Article

\title{
Free Trade versus Democracy and Social Standards in the European Union: Trade-Offs or Trilemma?
}

\author{
Claudia Wiesner \\ Department of Social and Cultural Sciences, Fulda University of Applied Sciences, 36037 Fulda, Germany; \\ E-Mail: claudia.wiesner@sk.hs-fulda.de
}

Submitted: 14 June 2019 | Accepted: 21 October 2019 | Published: 25 November 2019

\begin{abstract}
This article aims at conceptualising, in analytical as well as normative-theoretical terms, the tensions between free trade, democratic and social standards, and national sovereignty that are named in Dani Rodrik's "globalisation trilemma" for the case of the European Union (EU). It is argued that the trilemma concept is much more fitting to the EU than a simple trade-off concept. This model offers a conceptual path to both analysing existing tensions and thinking of resolving them: a) the EU has, indeed, been intervening into national democracies and national sovereignty as its legislation is superior to national legislation; b) EU legislation and judgements of the Court of Justice of the EU have been reducing national social standards; c) executives and numerous new institutions and agencies with indirect legitimation have taken over competencies that formerly lay in the domain of national directly legitimated legislatives; and d) these negative effects relate to the EU's giving preference to the liberalisation of free trade of capital, goods and services over democracy, social standards, and national sovereignty. Against the framework of the globalisation trilemma, analysis is combined with normative-theoretical judgements on the quality democracy of the setting that has been found and a conceptual discussion. The article concludes by discussing the perspectives of the setting examined and the possible paths to solutions, arguing that in order to keep a high level of economic integration, democracy, and social standards in the EU, national sovereignty needs to give way.
\end{abstract}

\section{Keywords}

democracy; European Union; free trade; globalisation trilemma; social standards

\section{Issue}

This article is part of the issue "Trade-Offs in the Political Realm: How Important Are Trade-Offs in Politics?" edited by Todd Landman (University of Nottingham, UK) and Hans-Joachim Lauth (University of Wuerzburg, Germany).

(C) 2019 by the author; licensee Cogitatio (Lisbon, Portugal). This article is licensed under a Creative Commons Attribution 4.0 International License (CC BY).

\section{Introduction}

This article aims at conceptualising, in analytical as well as normative-theoretical terms, the tensions between free trade, democratic and social standards, and national sovereignty that are named in the "globalisation trilemma" (Rodrik, 2011) for the case of the European Union (EU). I argue that the trilemma concept is much more fitting to the EU than a simple trade-off concept, as it offers a conceptual path to both analysing existing tensions and thinking of resolving them.

European integration has had a negative impact on democratic and social standards in the member states because: a) the EU has been intervening into national democracies and national sovereignty as its legislation is superior to national legislation; b) EU legislation and judgements of the Court of Justice of the EU (CJEU) have been reducing national social standards; and c) executives and numerous new institutions and agencies with indirect legitimation have taken over competencies that formerly lay in the domain of national directly legitimated legislatives (see Grimm, 2017; Scharpf, 1999; Wiesner, 2019). As will be discussed below, d) these negative effects relate to the EU's giving preference to the liberalisation of free trade of capital, goods and services over democracy, social standards, and national sovereignty. 
In the current discussion on the EU's impact on democracy and social standards, several contributions (see Section 2) argue that the EU endangers national democracy and national social standards. I share this critical diagnosis. There is, however, one part in these arguments that I do not share: they assume a trade-off between either an ongoing integration and trade liberalisation in the EU, or an upkeeping of democratic and social standards. In this article, I argue in favour of analysing trade liberalisation, democracy, and high social standards as a trilemma instead. The trilemma conception fits better with the complexity of the tensions at stake, and furthermore it offers a conceptual path to resolving them. This approach offers both an alternative perspective and a conceptual path to thinking about solutions.

The second section of this article analyses the EU's negative impact on democratic and social standards. Against the framework of the globalisation trilemma, I will analyse these tensions. The analysis will be followed by normative-theoretical judgements on the quality of democracy of the setting that has been found. The third section discusses why the tensions described should be conceptualised as a trilemma rather than a trade-off. The fourth section evaluates the state of the art of democratic and social standards in the EU. Finally, the fifth section develops the perspectives of following a path towards upkeeping high democratic and social standards in the EU at the expense of national sovereignty.

\section{Globalised Capitalism, the Globalisation Trilemma, and the EU: Conceptual Reflection and Analysis}

Over the last years, the academic debate has started to focus on the question whether democracy is compatible with globalised and financialised capitalism. Several authors agree that the dominance of a market-oriented financialised form of capitalism threatens representative democracy in its substance, with several contributions criticising the EU in this respect (e.g., Menéndez, 2015; Merkel, 2014; Somek, 2015; Streeck, 2014; Wiesner, 2016). The critical view on global financialised capitalism and its effects for democracy is in fit with Dani Rodrik's (2011) analysis. He states, first, that successful economies depend on successful democratic institutions: "Markets and governments are complements, not substitutes. If you want more and better markets, you have to have more (and better) governance. Markets work best not where the states are the weakest but where they are strong" (Rodrik, 2011, p. xviii).

This leads Rodrik (2011) to argue not only in favour of keeping good government, but also in favour of accepting that there is not only one path to economic prosperity, i.e., the path of trade deregulation. On the contrary: Using several examples, he demonstrates how in the case of many countries it was precisely economic intervention and regulation that led the path to economic success (Rodrik, 2011, pp. 135-158). The discussion leads Rodrik to present the conceptual framework of the:
Political trilemma of the world economy: We cannot simultaneously pursue democracy, national determination, and economic globalisation. If we want to push globalisation further, we have to give up either the nation state or democratic politics. If we want to maintain and deepen democracy, we have to choose between the nation state and international economic integration. And if we want to keep the nation state and self-determination, we have to choose between deepening democracy and deepening globalisation. Our troubles have their roots in our reluctance to face up these ineluctable choices. (Rodrik, 2011, pp. xviii-xix)

Rodrik, however, does not explicitly discuss the EU in his book. So why, as has been argued above, is the EU in fit with the argument of the globalisation trilemma (on the following see also Wiesner, 2016, 2017b, 2019)? The argument that out of three decisive political goalsfree trade, national sovereignty and national social security, and democracy-only two can be combined in a satisfactory manner explains the EU's current problems very well.

EU integration, as will be discussed in more detail throughout this article, has been strongly based on an intensification of free trade via creation of an internal market and the abolition of market barriers. As has been said above, this entailed a cutting down of national social and democratic standards. When conceptually applied to the $\mathrm{EU}$, the trilemma entails not just one, but three tradeoffs. The EU has to decide between having or keeping either: 1) national sovereignty, national social security, and free trade, i.e., cutting down democracy; 2) national sovereignty, national social security, and democracy, i.e., limiting free trade; or 3) free trade and democracy, i.e., cutting down national sovereignty. One cannot have all three of these at a time.

My argument is now that this trilemma not only describes a setting of three different trade-offs in the EU, it also allows to conceptualise a solution to an ongoing reduction of democratic and social standards via EU economic integration. I will, in the course of my argument, detail the conditions for reconciling democracy, social standards, and free trade in the EU: The EU needs to compensate for the losses of democratic and social standards on the national level. It then can become an example of free trade between nation-states not being a nuisance to democracy and social standards. But the path that combines internal free trade in the EU with keeping up high democratic and social standards leads to a reduction of national sovereignty, the third dimension of the trilemma.

In the following sections, I will describe how the realisation of the EU's liberal market rights collided with social and democratic standards in the member states. Two empirical examples shall be briefly sketched: a) a possible trade-off between trade liberalisation and social standards (Section 2.1); and b) a possible trade-off 
between financial liberalisation and national democracy (Section 2.2).

\subsection{A Trade-Off between Trade Liberalisation and National Social Standards?}

As has been said, European integration has been related to economic deregulation and trade liberalisation. The EU is based on the so-called four freedoms, i.e., free circulation of goods, people, services, and capital in the EU's inner market. After decades of market integration, these four freedoms today are realised. The CJEU (formerly European Court of Justice [ECJ]) played a decisive part in interpreting these principles and thus shaping legal and political practice. In its important judgements which were decisive for establishing legal and political standards in applying EU law, the Court mostly judged in favour of free trade-and often against national social standards (Grimm, 2017; Scharpf, 1999). What was tellingly termed "negative integration" by Fritz Scharpf (1999) thus affected national social standards. With this concept, Scharpf wants to emphasize that market creation in the EU, much more than on the creation of new rules and common standards ("positive integration"), was based on what he terms "negative integration," i.e., the abolition or reduction of national social standards because they were considered as obstacles to market integration (Scharpf, 1999).

Two judgements of the Court are illustrative for the effect of negative integration on social rights. The posted workers directive (EU, 2006) rules the conditions for workers that are posted into EU member states other than their home countries. The cases Rüffert and Laval referred to the working conditions in the state the workers were posted into, and also the right of trade unions to be protesting. In its judgements, the Court tried to interpret both these rights as narrow as possible, arguing explicitly that the posted workers directive was defining maximum rather than minimum standards. Member states receiving posted workers thus could claim the posting companies only to keep the standards defined in the directive, but not more.

In the Rüffert case (Dirk Rüffert $v$. Land Niedersachsen, 2008), the Court judged that the German federal state of Lower Saxony could not take action against a German company that did not pay agreed wages to the workers employed by a Polish subcontractor. In the Laval case (Laval un Partneri Ltd v Svenska Byggnadsarbetareförbundet, 2007), the Court even decided that national trade unions could only protest or get on strike against companies that were not resident in the respective member states in the few cases touched upon by the posted workers directive. In all other cases, legal action or strike against companies that sidetrack national social standards are excluded.

In these cases, the effects of European integration and trade liberalisation laws visibly worked along the lines of the globalisation trilemma, emphasising trade liberalisation in the $\mathrm{EU}$ at the expense of national sovereignty and national social standards. But, and this is a normative judgement, social rights are an elementary prerequisite of democracy (see in detail Wiesner, 2012, 2019, pp. 249-260) as social inequality hinders equal democratic participation and representation. Reducing social rights thus must be judged critically for its negative effects on equality and, ultimately, democracy.

Related to such arguments, one of the most critical accounts on the EU by Wolfgang Streeck $(2014,2015)$ establishes a clear and causal link between a decrease of welfare standards and democratic substance in the EU's member states and deregulation by the EU. Streeck (2014, $2015)$ therefore concludes that national sovereignty, national welfare states, and national democracies must be restored. In his view, capitalism should be de-globalised, and embedded democracy restored by re-embedding capitalism on the national level, which would also entail cutting down the EU (Streeck, 2015, pp. 59-60).

\subsection{A Trade-Off between the Effects of Financial Liberalisation and National Democracy?}

Second, and more recently, European integration has led to deteriorating or circumventing national democratic institutions, especially during the financial crisis and regarding the new institutions that have been set up. A system of supervision and new bodies developed, decisively cutting down competencies of national legislatives. Moreover, the new institutions make it difficult to determine who is to be held accountable for budgetary decisions and austerity. All this brought about numerous challenges for representative democracy in the EU multilevel system (e.g., Bellamy \& Weale, 2015; Crum, 2013; Laffan, 2016; Majone, 2014; Sanchez-Cuenca, 2017; on the following see also Wiesner, 2016, 2017b, 2019).

Depending on which level is concerned (EU or member states), which kind of measure and instrument (European Stability Mechanism [ESM], Six-pack, Twopack) and which status the respective state has (debtor or creditor), the effects of crisis governance on representative democracy vary (e.g., Fischer, 2016; Jančić, 2016; Maatsch, 2017). First, there are measures that fall under the regime of the Lisbon Treaty and have been voted upon with the participation of the European Parliament (EP), such as the Six-pack and Two-pack measures. Second, other measures are excluded from the treaty framework, such as the ESM. It is based on a new intergovernmental treaty and hence falls outside the official realm of the Lisbon Treaty and the checks and balances it establishes. Third, implementation of financial aid legislation has led to governmental attempts to strengthen executive dominance in many member states, for instance by using fast-track procedures in decisionmaking (Maatsch, 2017). The two latter points have led to serious consequences for representative democracy in the member states concerned. The case of financial aid governance is most pertinent here. 
In order to understand and analyse the setting of financial aid, one player is crucial: Article 137 of the Treaty on Functioning of the EU (TFEU) states that the 19 Euro states constitute the "Euro Group." It is closely related to both the Council of the European Union (Council in this text) and the European Council ${ }^{1}$, as the respective ministers of finance belong to the Council, and the respective heads of state and government to the European Council. But, as Protocol No. 14 of the Lisbon Treaty states, Euro Group meetings are informal (EU, 2016). This leads to a decisive difference in transparency: While Council meetings are public when the Council is acting in its legislative function, this is not the case for the Euro Group.

The ESM, which officially started on October 8th, 2012, is also related to the Euro Group. As the German Ministry of Finance explains, it is an intergovernmental financial institution and therefore subject to international law (Bundesfinanzministerium, 2017). Governance of financial aid has in large parts been concretely operated by the often cited "Troika," consisting of representatives of Commission, European Central Bank (ECB), and International Monetary Fund (IMF). Formally, the Troika is their agent and is charged with: a) negotiating the conditions of financial aid; and b) controlling that these conditions are kept. The ministers of finance and economics of the Euro states decide on financial aid and its conditions (European Council, 2012, Art. 5)-after the Troika has negotiated these conditions and fixed them in a "Memorandum of Understanding" (MoU). This MoU is signed by representants of the Commission in the name of the ESM (European Council, 2012, Art. 13, 3).

This means that the Troika not only is the agent that controls all conditions linked to any financial assistance, it is also in charge of negotiating these terms and putting them down in MoU. The Troika, accordingly, has a high degree of independence and considerable hard powerwhile it shows a low degree of accountability and transparency. The ESM Treaty defines the members and the general tasks of the Troika, but neither sets limits for its competencies nor establishes standards for its accountability. In particular, it remains unclear which competencies the Troika has over the member states, their governments, and their parliaments, how those competences refer to the Troika's principals, ECB, Commission, and IMF, and how they relate to the Euro Group's governments. It might be argued that such undefined competencies are an outcome of "incomplete contracting" as part of a principal-agent relation. Nevertheless, the structure is so opaque that it is difficult to see how the principals control the agent in the end.

But as the Troika negotiated the MoU, it de facto set the conditions for the national budgets. Accordingly, the most decisive change in the debtor states is to be seen in the fact that key standards of representative democracy are not followed anymore and decision-making powers in the budget procedure were handed over from the bodies that have been directly legitimised by the sovereign (national parliaments and governments) to bodies that either are only indirectly legitimised, such as the Euro Group, international non-majoritarian bodies, such as the IMF, or expert groups such as the Troika. But budgetary right is, for good reasons, understood as one of the crown jewels of a parliament: a budget symbolically and materially expresses the will of the parliamentary majority by defining the policies to be carried out in a country. A parliament that, in the end, cannot decide on details and between true alternatives regarding the budget, has lost the core of its role as a parliament. Decisions, then, not only are de-politicised, but also void of the substance of parliamentarism. In such cases, parliament takes on a referendum role (voting just Yes or No) rather than the parliamentary function of deliberation and vote. This also reduces the role and weight of the input legitimation once given by the sovereign in domestic elections: the legitimised national parliaments and governments whose decision-making powers have been cut down in substance (see in detail Wiesner, 2019).

This means that all crisis governance institutions brought a power shift from legislatives to executives and experts, both in the EU and in the member states. The financial aid part of crisis governance severely impedes national representative democracies and their balances of powers in the EU's multilevel system. In addition, the new intergovernmental institutions bypass the progresses to supranational representative democracy obtained in the EU over the last decades by excluding the EP. It is a decisive legitimisation problem to have shifted decisive parts of the decision-making competencies both outside the EU's and most of the national representative institutions.

Again, this scenario fits into the globalisation trilemma: The liberalisation of financial markets together with monetary integration first led to a crisis, and the attempts to remedy that crisis ultimately led to reducing national democratic standards. A number of recent contributions have underlined these problem fields. For instance, a special issue of the European Law Journal discusses financial crisis governance and its effects on democracy in terms of German constitutional lawyer Herman Heller's concept of authoritarian liberalism. Heller had, in a 1932 essay, linked upcoming authoritarianism to economic liberalism (Heller, 2015). In his discussion of Heller's essay, Alexander Somek speaks of a move towards authoritarian liberalism in the EU:

First, what emerges is a clear drive towards the centralisation of power. The autonomy of Member States to decide their fiscal and economic policies has been drastically curtailed....Second, the Eurozone has become equipped with the means to extend credit to

\footnotetext{
${ }^{1}$ The Treaty on European Union distinguishes the Council of the European Union, i.e., the Council of Ministers, and the European Council, i.e., the body representing the heads of state and government (European Union, 2016). When I mention the Council in the following, I refer to the Council of the European Union. The European Council is named as such.
} 
its Member States through the European Stability Mechanism....The granting of aid is closely tied to the so-called 'economic conditionality'....The conditionality is supposed to ensure that states are capable of sustaining the 'stability' of financial markets, which must not be upset by the state not back paying on either interest or principal debt. (Somek, 2015, p. 341)

Others have argued in a similar vein that the EU, especially in what I have termed its "crisis mode" (Wiesner, 2019), is in a state of emergency (Maatsch \& Cooper, 2017; White, 2015; see in detail Wiesner, 2019). In a slightly less dramatical tone, Claus Offe has highlighted that the crisis emphasised a discrepancy between executive dominance and governance of crisis measures and decreasing citizen support for the EU (Offe, 2015).

\section{Trilemma, Not Trade-Offs}

Returning to the conceptual questions, in this section I will further argue why the possible trade-offs sketched should, rather than as either-or constellations, be conceptualised as part of a trilemma. This is mainly because they are not unresolvable, but can be settled by making choices. If the EU sets up new democratic and social standards at the EU level and hence cuts down national sovereignty some more, it can keep up its high level of trade integration. To underline my argument, I will start by an analysis of the political and legal processes that have shaped the fields of conflict that have been sketched.

\subsection{Why Does the EU Challenge Democratic and Social Standards?}

Why did European integration lead to the outcome that was sketched? A first explanation is to be seen in the EU's historical origins. European integration started with the goals to create a balance of powers in Europe, to centralize control over the core industries of coal and steel, and to tame Western Germany. Economic integration was the tool for this, so the creation of an inner market for the first three decades of integration has been at the core of the integration process (Wiesner, 2014). Accordingly, the EU Treaties, i.e., the European Coal and Steel Community, the European Economic Community (EEC), and Euratom treaties and the ones that followed them, make a strong point of abolishing all obstacles to a free market economy and a successful inner market in the EU (or former EEC). Thus, the EU Treaties helped pave, and still do so, the way for market liberalisation, putting down all possible barriers to free trade, and even national social standards.

Besides the Treaties, a second decisive part was played by their interpreters, namely the Commission and the Court. Dieter Grimm (2017) knowingly describes the role of the latter, pointing out decisive factors. First, the Court acted as an agent of integration and deregulation.
Second, this limited the possibilities of member state governments to successfully shape and correct EU secondary law. Third, the EU Treaties as EU primary law regulate policy fields that normally should be subject to secondary law. Fourth, the Court became a major player in integration via its own judgements.

In two judgements in 1963 and 1964, the ECJ had claimed EU law to be superior to nation-state law, a move that has been interpreted as a constitutionalisation of the Treaties. But, different from national constitutions, the Treaties regulate a number of fields and issues that in a nation-state would belong to the field of secondary law, and, namely, economic policy rules. Decisive economic policy rules thus being of constitution-like character, it was not the legislative, but the judicative in the sense of the ECJ that had the strongest power to interpret them. In many cases, the ECJ decided in favour of abolishing obstacles to the inner market-even in the shape of national social standards. The ECJ therefore pushed negative integration in the sense of putting down market obstacles without creating new regulations. This is why Grimm (2017) judges the Court to follow a political agenda in favour of deregulation.

But the former ECJ was not alone in putting forward economic deregulation in the EU. The Treaties set the framework, but the Commission issued the respective law initiatives. Moreover, often enough, the EU legislators, i.e., member state governments and the EP, voted in favour of deregulation laws. But why?

The simplest explanation is policy preferences. From the 1970s onwards and, in particular, after the end of the social democrat era, governments deciding in the Council were increasingly led by conservatives and/or liberals, and economic policy was shaped by liberal market orientations. Governments not only shaped their national economic policies, but also deregulation policies in the EU via their votes in the Council. Discrepancies between richer and poorer EU member states favoured this: Negative integration is wished for by both rich and poor countries, as it facilitates market access and trade. Positive integration, that is, raising new standards, is not wished for by the poorer states, as they tend to profit from social dumping and a race to the bottom (Hix \& Høyland, 2011, pp. 209-215). The dynamics in the Council have become even more pertinent in the crisis as findings state that the Council became a more important decision-making forum alongside other intergovernmental institutions such as the Eurogroup (Fabbrini \& Puetter, 2016).

Since legislative co-decision between EP and Council has been introduced in Maastricht, the EP regularly codecided on the new inner market laws. Liberals and Conservatives were a decisive force in the EP as well, and often in the majority. The EP therefore could not present a serious obstacle to the deregulation agenda led by Commission, Council and ECJ. On the contrary: the EP approved of several of the new EU deregulation laws.

Another additional reason behind the decisionmaking of Council and EP is a self-binding, at first of the 
governments, but then also the EP majority, to the rules of the financial markets. As Wolfgang Streeck sketches in detail, the new common currency in the 1990s was prepared not by an economic government, but by a control of the criteria of convergence (Streeck, 2014, pp. 97-164) which have been anticipating today's austerity regime. Most member states, Commission, and EP in their majorities supported this self-binding to the markets from the 1990s onwards.

All this, first, is in fit with the economic Zeitgeist in favour of deregulation in the 1990s and 2000s that has been at length described by Dani Rodrik (2011) as one reason for the dominant directions in economic policies of the time. Second, it means that a complex setting of actors, interests, strategies, and political decisions led to economic deregulation in the EU. Besides the Court as a major driving force, Commission, member state governments, and also the EP have been deciding and codeciding in favour of deregulation-either because it was in their political interests, or because of a self-binding to financial austerity. The decrease of democratic and social standards that has been described above is a consequence of these policies. Third, there is political action and representative-democratic decision-making behind deregulation, and this means that it is possible that the actors in question decide and act otherwise.

\section{Democracy and Social Standards on the EU Level: State of the Art}

So far, I have discussed and conceptualised whether and to what extent the EU is entrapped in a trilemma. I have argued above that there are some crucial tensions between deregulation, trade liberalisation, social standards, and democracy to be noticed in the EU, but that none of these is an unresolvable or definite tradeoff. They rather have to be seen as part of a trilemma that allows for policy choices in favour of democratic and social standards. As a first conclusion, then, I argue that the globalisation trilemma presents a valuable framework for conceptualising and analysing tensions between trade liberalisation, national sovereignty, social standards, and democracy present in the EU.

On this basis, in this section I will argue in favour of the possible path to reconcile integration, a certain level of free trade, and democratic and social standards. We can aim for restoring democracy and social rights at the EU level itself and hence re-regulate free trade and its effects. But, and again, this is in fit with the globalisation trilemma, such a reconciliation would require resolving the trilemma at the expense of national sovereignty because the democratic procedures and the means of regulation of the EU level would need to be strengthened. This loss of national sovereignty of the member states would be linked to strengthening the EU as another level of democracy, social protection, and regulation. What are the perspectives for such a solution? Or has it already been partly achieved? What is hence the state of the art concerning democracy in the EU? And what about social standards? Analysis shows that there have been considerable achievements in these respects, but they are incomplete. Accordingly, if the loss of national democratic and social substance is to be compensated in the EU, the EU needs to be better democratised and social standards need to be better protected.

In short, the problems are decisively linked to an accumulation of seven problem fields (on the following see in detail Wiesner, 2019, pp. 281-301) that can be related to the globalisation trilemma's tensions that have been described. The problem fields that are most pertinent for the democratic deficits are: 1) an overbureaucratisation; 2) expert dominance; and 3) an overconstitutionalisation - these three reduce horizontal and vertical accountability and limit the space for political and public deliberation on politics and policies. The problem fields that impede social standards are: 4) differentiated integration; and 5) the effects of negative integration-these two cut down national democratic and social standards without creating them anew on the EU level. Two more problem fields relate to the EU's origin as an intergovernmental organisation and question whether national sovereignty in the EU should be further cut down. They are: 6 ) the lack of an idea and a practice of the EU common good; and 7) a weakly developed demos.

\subsection{Democratic Standards and Deficits in the EU}

The first three problem fields limit the quality of democracy in the $\mathrm{EU}$ :

1) Over-bureaucratisation: consensus-building and bureaucracy dominate in decision-making processes in the EU (see in detail Tömmel, 2014), at the expense of democratic deliberation and publicity. Processes such as trilogues (pre-negotiations between EP and Council representants that lead to most legal projects in the EU being accepted upon first readings) largely take place behind closed doors and in expert circles. Trilogues do not withdraw decisions from parliamentary decisionmaking as such. In trilogues, parliamentary committees and also the plenary are involved from the beginning to the end. The problem is one of weights and substance: if the most decisive part of the legislative process is carried out behind closed doors by experts in non-transparent negotiation circles, democratic accountability is reduced even if in the end parliament and its committees are involved just as they should be formally and legally (Reh, 2014; RoedererRynning \& Greenwood, 2015, 2017). Trilogues dedemocratise and de-politicize decision-making in the EU.

2) A number of expert bodies that have been created over the years possess executive competencies, 
and they are also largely withdrawn and decoupled from the realm of public representative decisionmaking. The EU's agencies, as well as private consultancy firms that do work for the Commission are examples here, but also the Troika (see in detail Wiesner, 2019, pp. 237-248).

3) Over-constitutionalisation: This problem is further emphasised by the Treaties themselves limiting the possible realm for democratic deliberation and decision-making. As described above, they fix decisive parts of the EU's economic governance with a quasi-constitutional character (see in detail Grimm, 2017), whereas in most national representative democracies, economic policymaking is subject to simple legislation.

The problem cluster of expert dominance, bureaucracy, and over-constitutionalisation in sum limits the realm for public deliberation and politicised decision-making. It limits accountability in both horizontal and vertical direction, and it limits transparency. But these problems could be reduced by just filling the democratic bodies that there are with active life. Concretely, the EP should use its co-decision powers to the fullest extent possible and shift the substantial weight of parliamentary debates and decisions back into the parliamentary and public bodies and arenas, away from trilogues. This would also increase the EP's horizontal accountability and legitimacy as well as its responsiveness. Furthermore, decision-making competencies should be taken away from indirectly legitimised agents such as the Troika: Decisions should be discussed and taken by the bodies that are directly legitimised for this, and that are directly accountable.

More room for democratic deliberation is possible and needed on the EU level and in the multi-level system. A broad solution here would be to de-constitutionalise the EU and to turn a large part of the EU's primary law into secondary law, in order for economic policy goalswhich currently are largely fixed by the Treaties-to be made subject to political debate and representativedemocratic politicised decision-making. But this change would depend on a major treaty change and again require unanimity of the member state governments, and in the EU's current situation it seems highly unlikely it could be obtained, especially as not all the member states governments (and Germany first in rank) would subscribe to the goal to politicize and democratize economic policymaking in the EU.

Nevertheless, a number of policy areas already are potentially subject to political and controversial deliberation and decision-making, both on the EU and on the national level. But the non-transparent decision-making structures and preferences of national governments that have been discussed above hinder open debate in many cases. Why shouldn't, for instance, austerity policies be debated in the Euro Group member states, in a similar vein as national pension scheme reforms? And why shouldn't debates about EP decisions on the budget be subject to EU wide political discussion? Similarly, it can be asked why Council and EC do not have more controversial and also more public political debates-at least the Council has a number or parliamentary functions (Palonen \& Wiesner, 2016) that could be more open to the public, just as in other parliaments.

\subsection{What Impedes Social Standards?}

The two next problem clusters both lead to downgrading national social standards and impede setting up new EU-wide social standards:

4) Differentiated integration: Different degrees of integration in different policy areas, and among different groups of member states, disperse the EU into a great variety of different regulation regimes and schemes. These range from co-decision in the inner market over the intergovernmentally structured Common Foreign and Security Policy, the Euro Group that just unites the Euro-Countries, to the Schengen System. This dispersion of governance modes in a polity as big as the EU does not simply create differing patterns of legitimisation and control: if it is unclear, even to experts, who has taken a decision and what way the decisionmaking process went, democratic accountability and transparency are also clearly hampered.

5) Negative integration: As said above, the EU negative integration (i.e., the abolition of markethindering regulations) dominates over positive integration (i.e., re-regulation; Scharpf, 1999). Negative integration has cut down national democratic standards and achievements such as social citizenship rights (see in detail Wiesner, 2019, pp. 249-260). Moreover, there has not been a compensation on the EU level. EU-related citizenship rights are mainly market-related freedom rights, with the addition of a core set of political rights linked to Union Citizenship. Social rights have rarely been defined on the EU level so far. As has been explained above, besides a harmonisation of some basic social standards, positive integration in the sense of setting up new EU related social rights has been difficult to obtain because of diverging interests of the member states.

The effects of both differentiated integration and negative integration need to be limited, especially when it comes to achievements that are crucial for democratic standards. In brief (for detailed discussions see Wiesner, 2017a, 2017b) there are two possible ways that refer to either upkeeping the trilemma and its tensions, or to resolving it at the expense of national sovereignty:

a) There is a narrow solution: In policy areas ruled by the EU, democratic and social standards in the 
member states must be protected and negative integration hindered. This could, for instance, happen via EU laws that exclude any intervention into national democratic and social standards even in times of financial aid. If the MoU, for instance, only fixed the sums to be cut in the budgets rather than the related policies as well, national parliaments would keep much more decision-making powers.

This solution, nota bene, is a defensive one because following the argument above, national democratic standards are in permanent latent tension with free trade in the EU, and this permanent tension can only be resolved if they are ultimately transferred to the EU. As long as this is not the case-mainly because of the reasons discussed in the concluding section-it is an interim protection mechanism to keep up national standards. The trilemma in this scenario is kept.

b) In the broad solution, new democratic and social standards would be created at the EU level as the EU would be fully integrated, national sovereignty would be decisively cut down, and the trilemma would be resolved into one direction. The EU would then decide or co-decide in all, or almost all, of the policies that are currently ruled by democratic nation-states. This would stop differentiated integration and submit all policy areas to one mode of legitimation, but it would require a number of changes that are neither realist nor workable in the moment, such as EU taxes to finance EU redistribution and common social standards to safeguard one and the same level of protection everywhere.

\section{The EU's Common Good versus National Sovereignty}

I have argued that, in order to resolve the tensions between trade liberalisation and deregulation on one hand and democratic and social standards in the EU on the other, it is necessary to strengthen democratic and social standards on the EU level. This claim immediately leads to the third trilemma dimension, the one of national sovereignty. As argued above, it is a consequence that it needs to be cut down somewhat further.

As long as this is not the case, an inbuilt tension inherent to the EU will have its way that relates to the last two problem clusters at stake. As intergovernmental and supranational dynamics coexist and are represented in the EU's institutions, these are only partly led by an orientation towards an EU common good, and they are only weakly related to an EU demos:

6) The EU's common good: The EU's supranational bodies-the EP and the Commission-are oriented towards the EU's common good, while the intergovernmental bodies-the Council of the European Union and the European Council-are oriented towards the national particular interests (see in detail Tömmel, 2014, pp. 324-330). Moreover, while national governments work in a short-term logic as they want to be re-elected, EU institutions are much more independent from electoral choices (see in detail Hix \& Høyland, 2011). This situation creates a tension and a tendency in the EU's system that in a very general way hinders an overall orientation to an EU common good. Such an orientation, however, should be a basic principle of all institutions of a democratic polity. So far, there is not only a weak level of institutional orientation towards an EU common good, there is also no agreement what this common good is about. Should the EU just continue to create an inner market, as it did? Or should it become a truly supranational federation?

7) These questions lead to asking how the distance between EU citizens and elites can be reduced, and how the EU citizenry could turn into a stronger demos, i.e., a real and active democratic subject.

It is immediately evident that these two last problem clusters directly relate to national sovereignty and the questions to what extent a common good can be supranational rather than national, and in what respect a demos can be EU-related rather than nation-state-oriented. One answer given in the academic debate is that the EU must continue not as democracy, but as demoi-cracy, i.e., as an organisation that continues to be based on the democratic input legitimacy of the member states national demoi (see, e.g., Cheneval \& Schimmelfennig, 2013; Nicolaïdis, 2013). My argument is obviously-and for a number of reasons-opposed to this view.

As I have argued above, the tensions between democracy, free trade, and social standards in the EU must be seen in their interrelations in the multi-level system between the EU and its member states. If one sticks only to the nation-states and their demoi as resource of legitimation, the tensions inflicted by trade liberalisation in the EU remain unchanged and will continue to challenge democratic and social standards. As I have argued, the only way to resolve the trilemma without reducing either democratic or social standards-or without cutting down economic EU integration-is to strengthen democratic standards at EU level and to keep social standards intact, or even better, set them up at EU level as well.

If the member states agreed to this, to protect and create new democratic and social standards, in principle the EU could use the same means that helped to embed capitalism in the nation-state context: laws that regulate trade and protect democracy, accompanied by political debates and representative democratic decision-making on the goals of economic policy. But, as said, this would require treaty changes (making economic policy subject to secondary legislation) and hence unanimity between the EU's governments in the Council, and this prospect does not seem realist at the moment. 
As long as such a thorough treaty change is not to be obtained, an interim solution is a compromise. The tensions of the trilemma can be soothed via a mix of different measures and steps that combine mechanisms that strengthen democracy in the EU and help re-regulate the effects of negative integration, without completely playing down the role of the national democratic systems, and while upkeeping their democratic standards. In addition, protection mechanisms in the multi-level system are needed which safeguard what social standards have been achieved. But, to conclude, it needs to be underlined that the tensions described by the trilemma conception are impossible to be completely resolved. If no clear option in the trilemma can be achieved, it can only be hedged in a probably permanently instable way.

\section{Acknowledgments}

This research was partly carried out during a Visiting Fellowship at the Minda de Gunzburg Centre at Harvard University in Spring 2019. The Visiting fellowship was co-funded by a Grant from Fritz-Thyssen foundation: "EU Multilevel Democracy in Crisis Mode" and by the Research Centre for Intercultural and European Studies (CINTEUS) at Fulda University of Applied Sciences. I also acknowledge support by the Open Access Publishing Fund of Fulda University of Applied Sciences.

\section{Conflict of Interests}

The author declares no conflict of interests.

\section{References}

Bellamy, R., \& Weale, A. (2015). Political legitimacy and European monetary union: Contracts, constitutionalism and the normative logic of two-level games. Journal of European Public Policy, 22(2), 257-274. https://doi.org/10.1080/13501763.2014.995118

Bundesfinanzministerium. (2017). Fragen und Antworten zum Europäischen Stabilitätsmechanismus (ESM) [Questions and answers on the European Stability Mechanism (ESM)]. Bundesministerium der Finanzen. Retrieved from http://www. bundesfinanzministerium.de/Content/DE/FAQ/201208-16-esm-faq.html

Cheneval, F., \& Schimmelfennig, F. (2013). The case for demoicracy in the European Union. JCMS: Journal of Common Market Studies, 51(2), 334-350. https:// doi.org/10.1111/j.1468-5965.2012.02262.x

Crum, B. (2013). Saving the Euro at the cost of democracy? JCMS: Journal of Common Market Studies, 51(4), 614-630. https://doi.org/10.1111/jcms. 12019

Dirk Rüffert v. Land Niedersachsen, C-346/06 (3 April 2008). Retrieved from http://curia.europa.eu/juris/ liste.jsf?language $=$ de $\&$ num $=c-346 / 06 \#$

European Council. (2012). Treaty establishing the Euro- pean Stability Mechanism (T/ESM 2012). Brussels: European Council. Retrieved from https://www.esm. europa.eu/legal-documents/esm-treaty

European Union. (2006). Directive 2006/123/EC of the European Parliament and of the Council of $12 \mathrm{De}$ cember 2006 on services in the internal market (Document 32006L0123). Brussels: European Union. Retrieved from http://eur-lex.europa.eu/legal-content/ EN/TXT/PDF/?uri=CELEX:32006L0123\&from=DE

European Union. (2016). Consolidated version of the Treaty on European Union. Brussels: European Union.

Fabbrini, S., \& Puetter, U. (2016). Integration without supranationalisation: Studying the lead roles of the European Council and the Council in postLisbon EU politics. Journal of European Integration, 38(5), 481-495. https://doi.org/10.1080/07036337. 2016.1178254

Fischer, T. (2016). Viele Gesichter, ein Demokratiedefizit? [Many faces, one democratic deficit?]. Paper presented at the Workshop "Demokratische Steuerung der EU-Krisen-Ein Ding der (Un)möglichkeit?!" [Democratic governance of the EU's crises-Mission (im)possible?!], Darmstadt, Germany.

Grimm, D. (2017). The constitution of European democracy (1st ed.). Oxford: Oxford University Press.

Heller, H. (2015). Authoritarian liberalism? European Law Journal, 21(3), 295-301. https://doi.org/10.1111/ eulj.12125

Hix, S., \& Høyland, B. K. (2011). The political system of the European Union (3rd ed.). Basingstoke: Palgrave Macmillan.

Jančić, D. (2016). National parliaments and EU fiscal integration. European Law Journal, 22(2), 225-249. https://doi.org/10.1111/eulj.12172

Laffan, B. (2016). Europe's union in crisis: Tested and contested. West European Politics, 39(5), 915-932. https://doi.org/10.1080/01402382.2016.1186387

Laval un Partneri Ltd v. Svenska Byggnadsarbetareförbundet, C-341/05 (18 December 2007). Retrieved from http://curia.europa.eu/juris/liste.jsf?language=en \& num $=C-341 / 05$

Maatsch, A. (2017). Parliaments and the economic governance of the European Union: Talking shops or deliberative bodies? New York, NY: Routledge.

Maatsch, A., \& Cooper, I. (2017). Governance without democracy? Analysing the role of parliaments in European economic governance after the crisis: Introduction to the special issue. Parliamentary Affairs, 70(4), 645-654. https://doi.org/10.1093/pa/gsx018

Majone, G. (2014). From regulatory state to a democratic default. JCMS: Journal of Common Market Studies, 52(6), 1216-1223. https://doi.org/10.1111/jcms. 12190

Menéndez, A. J. (2015). Hermann Heller NOW. European Law Journal, 21(3), 285-294. https://doi.org/ 10.1111/eulj.12135

Merkel, W. (2014). Is capitalism compatible with democracy? Zeitschrift für Vergleichende Politikwis- 
senschaft, 8(2), 109-128. https://doi.org/10.1007/ s12286-014-0199-4

Nicolaïdis, K. (2013). European demoicracy and its crisis. JCMS: Journal of Common Market Studies, 51(2), 351-369. https://doi.org/10.1111/jcms.12006

Offe, C. (2015). Europe entrapped. Cambridge: Polity Press.

Palonen, K., \& Wiesner, C. (2016). The European Council: Second chamber, congress of ambassadors or federal presidency? Parliaments, Estates and Representation, 36(1), 71-89.

Reh, C. (2014). Is informal politics undemocratic? Trilogues, early agreements and the selection model of representation. Journal of European Public Policy, 21(6), 822-841. https://doi.org/10.1080/13501763. 2014.910247

Rodrik, D. (2011). The globalization paradox: Democracy and the future of the world economy. New York, NY: W. W. Norton \& Company.

Roederer-Rynning, C., \& Greenwood, J. (2015). The culture of trilogues. Journal of European Public Policy, 22(8), 1148-1165. https://doi.org/10.1080/ 13501763.2014.992934

Roederer-Rynning, C., \& Greenwood, J. (2017). The European Parliament as a developing legislature: Coming of age in trilogues? Journal of European Public Policy, 24(5), 735-754. https://doi.org/10.1080/13501763. 2016.1184297

Sanchez-Cuenca, I. (2017). From a deficit of democracy to a technocratic order: The postcrisis debate on Europe. Annual Review of Political Science, 20, 351-369. https://doi.org/10.1146/annurev-polisci061915-110623

Scharpf, F. W. (1999). Governing in Europe. Oxford: Oxford University Press.

Somek, A. (2015). Delegation and authority: Authoritarian liberalism today. European Law Journal, 21(3), 340-360. https://doi.org/10.1111/eulj.12132

Streeck, W. (2014). Buying time: The delayed crisis of democratic capitalism. Brooklyn, NY: Verso.
Streeck, W. (2015). Comment on Wolfgang Merkel, "Is capitalism compatible with democracy?" Zeitschrift für Vergleichende Politikwissenschaft, 9(1/2), 49-60. https://doi.org/10.1007/s12286-015-0232-2

Tömmel, I. (2014). The European Union: What it is and how it works. Houndsmills: Palgrave Macmillan.

White, J. (2015). Emergency Europe. Political Studies, 63(2), 300-318. https://doi.org/10.1111/1467-9248. 12072

Wiesner, C. (2012). Bürgerschaft, Demokratie und Gerechtigkeit in der EU [Citizenship, democracy, and justice in the EU]. In R. Kreide, C. Landwehr, \& K. Töns (Eds.), Demokratie und Gerechtigkeit in Verteilungskonflikten [Democracy and justice in distribution conflicts] (pp. 185-210). Baden-Baden: Nomos.

Wiesner, C. (2014). From safeguarding peace in Europe to financial crisis: Old questions and new challenges of EU integration. In C. Wiesner \& M. Schmidt-Gleim (Eds.), The meanings of Europe (pp. 91-106). London: Routledge.

Wiesner, C. (2016). Capitalism, democracy, and the European Union. Zeitschrift für Vergleichende Politikwissenschaft, 10(3/4), 219-239. https://doi.org/10. 1007/s12286-016-0320-y

Wiesner, C. (2017a). Möglichkeiten und Grenzen repräsentativer Demokratie in der EUFinanzhilfenpolitik. [Chances and limits of representative democracy in the EU politic of financial aid] Integration, 1, 33-47.

Wiesner, C. (2017b). Representative democracy in times of austerity: New challenges in the EU multi-level system. In R. Sturm, T. Griebel, \& T. Winkelmann (Eds.), Austerity: A journey to an unknown territory: Discourses, economics and politics (pp. 287-304). Baden-Baden: Nomos.

Wiesner, C. (2019). Inventing the EU as a democratic polity: Concepts, actors and controversies. London: Palgrave Macmillan.

\section{About the Author}

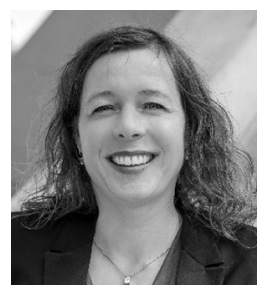

Claudia Wiesner is Jean Monnet Chair and Professor for Political Science at Fulda University of Applied Sciences as well as Adjunct Professor in Political Science at Jyväskylä University. Her main research interests lie in the comparative study of democracy, political culture, and political sociology in the EU multilevel system. She especially focuses on changes of concepts and institutions, as well as on the related debates and discourses. 